\title{
Respon Pertumbuhan dan Produksi Andrographolida Tanaman Sambiloto (Andrographis paniculata Nees.) Akibat Perbedaan Dosis Pupuk Guano
}

\author{
Suhartono ${ }^{1 *}$, Diana Nurus Sholehah ${ }^{2)}$, Rohmad Suci Murdianto ${ }^{3)}$ \\ 1,2,3) Agroekoteknologi, Universitas Trunojoyo Madura \\ 1) suhartono@trunojoyo.ac.id, ${ }^{2)}$ diananurus@yahoo.co.id, ${ }^{3)}$ rsmurdianto@gmail.com
}

DOI: https://doi.org/10.21107/rekayasa.v13i2.6905

\begin{abstract}
Response of Growth and Production of Srographic Andrographolida Plants (Andrographis paniculata Nees.) Due to Differences in Guano Fertilizer Doses
\end{abstract}

\begin{abstract}
Bitter plant (Andrographis paniculata Nees.) including one featured Indonesian medicinal plants in addition to ginger, noni, gotu kola, aloe vera, pepper, and turmeric. Increased productivity is bitter to do with the improvement of farming techniques through a system of fertilization. Study of guano fertilizer application on the growth, production, and content andrographolide the bitter plant is limited, so it is necessary to know the effect of guano fertilizer on the growth and content of the plant andrographolide bitter. This research was conducted at the experiment station University of Trunojoyo Madura at January until April 2016 by using a completely randomized design (RAL) non-factorial with 4 replications consisting of G0 (control/without guano fertilizer), G1 ( fertilizer guano 5 tons/ha) G2 (7.5 tons/ha), G3 (10 tons/ha), G4 (12.5 tons/ha) and G5 (15 tons/ha) on each trial there are 6 plants with details of 3 plants in the sample. The results showed that the guano fertilizer at a dose of 15 tons/ha (G5) can be increased plant height, leaf number, leaf area, total wet weight, and total dry weight. The highest content of andrographolide obtained at doses of 7.5 tons/ha (G2) of guano fertilizer, while the highest yield of andrographolide obtained at doses 12.5 tons/ha of guano fertilizer (G4).
\end{abstract}

Keywords: Bitter, Guano Fertilizer, Growth, Yield Andrographolide

\section{ABSTRAK}

Tanaman sambiloto (Andrographis paniculata Nees.) merupakan salah satu tanaman obat unggulan Indonesia selain temulawak, mengkudu, pegagan, lidah buaya, lada, dan kunyit. Peningkatan produktivitas sambiloto dapat dilakukan dengan perbaikan teknik budidaya melalui sistem pemupukan. Kajian aplikasi pupuk guano terhadap pertumbuhan, produksi dan kandungan andgrographolida pada tanaman sambiloto terbatas, sehingga perlu dilakukan untuk mengetahui pengaruh pupuk guano terhadap pertumbuhan dan kandungan andrographolida pada tanaman sambiloto. Penelitian ini dilaksanakan di kebun percobaan Universitas Trunojoyo Madura pada bulan Januari sampai April 2016. Penelitian ini menggunakan Rancangan Acak Lengkap (RAL) non faktorial dengan perlakuan 6 taraf dosis pupuk guano dengan 4 ulangan. Perlakuan dosis pupuk guano per hektar meliputi G0 (control/tanpa pupuk guano), G1 (5 ton), G2 (7.5 ton), G3 (10 ton), G4 (12.5 ton), dan G5 (15 ton). Pada setiap percobaan terdapat 6 tanaman dengan rincian 3 tanaman sebagai sampel. Hasil penelitian menunjukan bahwa pemupukan guano pada dosis 15 ton/ha (G5) memberikan hasil terbaik untuk parameter tinggi tanaman, jumlah daun, luas daun, berat basah total dan berat kering total tanaman. Kandungan andrographolida (\%) tertinggi diperoleh pada dosis pupuk guano 7.5 ton/ha (G2), sedangkan produksi andrograpolida (mg) tertinggi ditunjukkan oleh perlakuan G4 (dosis pupuk guano 12.5 ton/ha).

Keywords: Sambiloto, Pupuk Guano, Pertumbuhan, Produksi Andrographolida

\section{PENDAHULUAN}

Tanaman sambiloto (Andrographis paniculata Nees.) merupakan salah satu tanaman obat unggulan di Indonesia. Tanaman ini telah banyak diteliti secara etnobotani, penyebaran, botani, budidaya, efek farmakologis, kandungan kimia, uji praklinis dan uji klinis. Penggunaan sambiloto sebagai obat sudah terbukti secara nyata, efektif, aman, berkhasiat (Winarto dan Karyasari, 2004).

Selama ini bahan baku tanaman obat sambiloto diambil dari habitat alami. Apabila hal ini terus

\section{Article History:}

Received: March, 19 th 2020; Accepted: May, 10 2020

REKAYASA ISSN: 2502-5325 has been Accredited by Ristekdikti (Arjuna) Decree: No. 23/E/KPT/2019 August $8^{\text {th }}$, 2019 effective until 2023 menerus dilakukan tanpa adanya budidaya kemungkinan besar bahan baku obat yang ada di alam akan mengalami kelangkaan. Selain itu simplisia yang dihasilkan oleh bahan alam tidak stabil dan kualitasnya tidak dapat dipertahankan. Menurut Kartosapoetra, (1992) mengatakan bahwa pengumpulan simplisia dari tanaman obat yang dibudidayakan dengan baik akan memberikan penyediaan bahan obat yang terjamin kualitasnya, karena tidak ada kemungkinan tercampur bahan tanaman lain. Oleh karena itu perlu pembudidayaan tanaman

\section{Cite this as:}

Suhartono, S., Sholehah, D.N., \& Murdianto, R.S. (2020). Respon Pertumbuhan dan Produksi Andrographolida Tanaman Sambiloto (Andrographis paniculata Nees.) Akibat Perbedaan Dosis Pupuk Guano. Rekayasa, 13(2), 164-171. https://doi.org/10.21107/rekayasa.v13i2.6905 
sambiloto yang tepat agar memperoleh simplisia dan kandungan andrographolida yang lebih baik.

Selain faktor media tanam, factor pemupukan merupakan salah satu cara yang dapat dilakukan untuk memenuhi ketersediaan unsur hara tanah yang dibutuhkan tanaman. Dengan adanya pemupukan, tanaman dapat tumbuh optimal dan menentukan mutu kualitas hasil simplisia sambiloto. Salah satu yang mempengaruhi kandungan andrographolida adalah kadungan unsur hara P. Hal ini karena andrographolida termasuk dalam golongan diterpen. Diterpen merupakan elaborasi dari geranil - geranil pirofosfat (Herbert, 1995).

Salah satu pupuk yang memiliki kandungan $\mathrm{P}$ yaitu pupuk guano. Pupuk guano merupakan kotoran dari burung kelelawar, pupuk ini terhitung pupuk yang tidak kalah dibandingkan dengan pupuk lainnya. Menurut penelitian, kotoran burung kelelawar banyak mengandung unsur hara bagi tanaman karena berisi biji-bijian yang berasal dari tanaman (Lingga dan Marsono, 2000). Pupuk ini kaya akan unsur hara makro seperti nitrogen $15 \%$, phosfor $54 \%$, dan $1,7 \%$ kalium yang berguna untuk memperbaiki struktur tanah (Sedyarso, 1999).

Namun pemupukan atau pemberian nutrisi saja tidak cukup tanpa mengetahui banyaknya kebutuhan nutrisi yang dibutuhkan tanaman. Untuk itu perlu diketahui dosis pupuk yang tepat sehingga pertumbuhan dan perkembangan tanaman sambiloto memberikan hasil yang baik (Pujiasmanto et al., 2009). Oleh karena itu perlu adanya penelitian untuk mengetahui pengaruh pupuk guano terhadap pertumbuhan dan kandungan andrographolida pada tanaman sambiloto (Andrographis paniculata Nees.).

\section{METODE PENELITIAN}

Penelitian ini dilaksanakan di kebun percobaan program Studi Agroekoteknologi Fakultas Pertanian Universitas Trunojoyo Madura di Desa Telang, Kecamatan Kamal, Kabupaten Bangkalan, Madura. Ketinggian tempat $\pm 600 \mathrm{~m} \mathrm{dpl}$. Penelitian ini dilaksanakan pada akhir Bulan Januari 2016 sampai pertengahan bulan april 2016.
Alat yang digunakan dalam penelitian ini antara lain cangkul, timbangan, oven, rol meter, mistar, alat tulis, dan yang dapat mendukung pelaksanaan penelitian ini.

Bahan yang digunakan dalam penelitian ini adalah benih sambiloto yang diperoleh dari Materia Medica Batu Malang, pupuk guano, tanah mediteran, arang sekam, pupuk kandang sapi, paranet $25 \%$, ajir, potray untuk pembibitan dan polybag $35 \mathrm{~cm} \times 35 \mathrm{~cm}$ untuk penanaman.

Penelitian menggunakan Rancangan Acak Lengkap (RAL) non faktorial dengan 6 perlakuan dan 4 ulangan. Setiap satuan percobaan terdapat 6 tanaman dengan rincian 3 tanaman sebagai sampel. Adapun faktor perlakuan tersebut adalah:

$\mathrm{G0}=$ tanpa pemupukan (kontrol)

G1 = Pupuk Guano 5 ton/ha

$\mathrm{G} 2$ = Pupuk Guano 7,5 ton/ha

$\mathrm{G} 3$ = Pupuk Guano 10 ton/ha

G4 = Pupuk Guano 12,5 ton/ha

G5 = Pupuk Guano 15 ton/ha

Untuk mengetahui pengaruh perlakuan dilakukan analisis dengan menggunakan Analysis of Varian (Anova), dan apabila berpengaruh nyata dilanjutkan dengan uji Beda Jujur Nyata Duncan (BJND) taraf $5 \%$.

\section{HASIL DAN PEMBAHASAN}

\section{Tinggi Tanaman}

Hasil analisis sidik ragam menunjukkan bahwa tinggi tanaman akibat perlakuan berbagai dosis pupuk guano menunjukkan tidak berpengaruh nyata pada umur 2 MST, namun berpengaruh nyata pada umur $4,6,8,10$, dan 12 MST.

Tabel 1 menunjukkan nilai rata-rata tinggi tanaman tertinggi terdapat pada perlakuan dosis pupuk guano 15 ton (G5) pada semua umur tanaman (2 - 12 MST). Sedangkan nilai rata-rata terendah terdapat pada perlakuan tanpa pupuk guano (G0).

Tabel 2 menunjukkan rata-rata jumlah daun dengan nilai tertinggi terdapat pada perlakuan dosis pupuk guano 15 ton (G5) pada semua umur tanaman (2 - 12 MST), yaitu 6.00, 9.75, 28.58, 
Tabel 1. Rata-rata Tinggi Tanaman (cm) Sambiloto Akibat Perlakuan Dosis Pupuk Guano Pada Berbagai Umur Tanaman (MST)

\begin{tabular}{|c|c|c|c|c|c|c|c|c|c|c|c|}
\hline \multirow{2}{*}{ Perlakuan } & \multicolumn{11}{|c|}{ Rata-rata Tinggi Tanaman $(\mathrm{cm})$ pada Umur Pengamatan } \\
\hline & 2 & 4 & & 6 & & 8 & & 10 & & 12 & \\
\hline G0 & 3,77 & 4,91 & a & 11,39 & a & 29,14 & a & 46,78 & a & 59,56 & a \\
\hline G1 & 3,77 & 5,64 & $\mathrm{~b}$ & 12,63 & $\mathrm{~b}$ & 30,34 & $a b$ & 47,96 & $a b$ & 61,34 & $a b$ \\
\hline G2 & 3,78 & 5,69 & $b$ & 12,90 & $b c$ & 30,39 & $a b$ & 48,50 & $a b$ & 61,88 & $a b$ \\
\hline G3 & 3,82 & 5,71 & $b$ & 12,91 & $b c$ & 31,03 & $a b$ & 49,33 & $a b c$ & 63,46 & $a b c$ \\
\hline G4 & 3,82 & 6,17 & $b$ & 13,87 & $\mathrm{~cd}$ & 32,73 & $\mathrm{bc}$ & 50,76 & bc & 65,14 & bc \\
\hline G5 & 4,13 & 7,13 & c & 14,90 & $d$ & 34,04 & c & 52,44 & c & 67,09 & C \\
\hline BJND 5\% & ns & * & & * & & * & & * & & * & \\
\hline
\end{tabular}

Keterangan : Angka-angka yang diikuti huruf yang sama pada kolom yang sama tidak berbeda nyata berdasarkan uji BJND 5\% ;

ns : non signifikan ;

* : berpengaruh nyata

Tabel 2. Rata-rata Jumlah Daun (helai) Akibat Perlakuan Dosis Pupuk Guano Pada Berbagai Umur Tanaman (MST)

\begin{tabular}{|c|c|c|c|c|c|c|c|c|c|}
\hline \multirow{2}{*}{ Perlakuan } & \multicolumn{9}{|c|}{ Rata-rata Jumlah Daun (helai) Pada umur Pengamatan } \\
\hline & 2 & 4 & 6 & 8 & & 10 & & 12 & \\
\hline G0 & 6,00 & 9,00 & 25,50 & 71,17 & a & 157,50 & a & 274,08 & a \\
\hline G1 & 6,00 & 9,50 & 26,17 & 73,33 & $a b$ & 160,83 & a & 280,25 & $a b$ \\
\hline G2 & 6,00 & 9,50 & 27,34 & 77,92 & $a b c$ & 163,75 & $\mathrm{a}$ & 283,59 & $a b$ \\
\hline G3 & 6,00 & 9,50 & 27,58 & 81,59 & $\mathrm{bc}$ & 178,50 & $b$ & 298,00 & $b c$ \\
\hline G4 & 6,00 & 9,50 & 28,17 & 85,67 & $\mathrm{~cd}$ & 184,00 & $b$ & 308,17 & $\mathrm{~cd}$ \\
\hline G5 & 6,00 & 9,75 & 28,58 & 91,92 & $d$ & 189,34 & $b$ & 320,50 & $d$ \\
\hline BNJD 5\% & ns & ns & ns & * & & * & & * & \\
\hline
\end{tabular}

Keterangan: Angka-angka yang diikuti huruf yang sama pada kolom yang sama tidak berbeda nyata berdasarkan uji BJND 5\% ;

ns: non signifikan ;

* : berpengaruh nyata

91.92, 189.34 dan 320.50 helai. Sedangkan nilai rata-rata jumlah daun terendah terdapat pada perlakuan tanpa pupuk guano (G0) pada semua umur tanaman (2 - 12 MST), yaitu 6.00, 9.00, $25.50,71.17,157.50$ dan 274.08 helai.

\section{Luas Daun $\left(\mathrm{cm}^{2}\right)$}

Hasil analisis sidik ragam pada parameter luas daun tanaman menunjukkan bahwa perlakuan dosis pupuk guano tidak berpengaruh nyata pada umur 2, 4, dan 6 MST sedangkan pada umur 8, 10, dan 12 MST memberikan berpengaruh nyata. Rata-rata luas daun tanaman disajikan pada Tabel 3.
Pada Tabel 3 terlihat nilai rata-rata luas daun tertinggi terdapat pada perlakuan G5 dan nilai rata-rata luas daun terendah terdapat pada perlakuan tanpa pupuk guano (G0).

\section{Berat Basah (g), Berat Kering (g) dan Kadar Andrographolida Tanaman Sambiloto (\%)}

Hasil analisis sidik ragam menunjukkan bahwa perlakuan dosis pupuk guano berpengaruh nyata terhadap parameter berat basah, berat kering dan kandungan andrograpolida tanaman sambiloto. Data rata-rata berat basah, berat kering dan kandungan androdrapolida disajikan pada Tabel 4. 
Tabel 4. menunjukkan berat basah tanaman tertinggi terdapat pada perlakuan dosis pupuk Guano 15 ton/ha (G5) yaitu 102.65 g, sedangkan untuk nilai rata-rata terendah terdapat pada perlakuan tanpa pupuk guano (G0) yaitu $78.94 \mathrm{~g}$. Nilai rata-rata berat kering tanaman tertinggi dihasilkan oleh perlakuan dosis pupuk guano 15 ton/ha (G5) yaitu $21.33 \mathrm{~g}$, sedangkan untuk nilai rata-rata terendah terdapat pada perlakuan tanpa pupuk guano (G0) yaitu $15.89 \mathrm{~g}$.

Sedangkan untuk kandungan andrograpolida, nilai rata-rata tertinggi terdapat pada perlakuan 7.5 ton/ha pupuk guano (G2) yaitu $4.49 \%$, sedangkan nilai rata-rata terendah terdapat pada perlakuan tanpa pupuk guano (G0) yaitu $3.90 \%$.

Secara umum pertumbuhan dan perkembangan tanaman terdiri dari dua fase yang berbeda yaitu fase vegetatif dan generatif. Fase vegetatif terutama terjadi pada perkembangan akar, daun dan batang baru. Pada fase generatif terjadi pada pembentukan dan perkembangan kuncupkuncup bunga, bunga dan biji (Harjadi, 1996). Penelitian tentang pengaruh pupuk guano terhadap pertumbuhan dan kandungan andrographolida pada tanaman sambiloto (Andrographis paniculata Nees.) menunjukkan

Tabel 3. Rata-rata Luas Daun $\left(\mathrm{cm}^{2}\right)$ Sambiloto Akibat Dosis Pupuk Guano Pada Berbagai Umur Tanaman (MST)

\begin{tabular}{|c|c|c|c|c|c|c|c|c|c|}
\hline \multirow{2}{*}{ Perlakuan } & \multicolumn{9}{|c|}{ Rata-rata Luas Daun ( $\left.\mathrm{cm}^{2}\right)$ Pada Umur Pengamatan } \\
\hline & 2 & 4 & 6 & 8 & & 10 & & 12 & \\
\hline G0 & 3,42 & 39,63 & 292,47 & 964,49 & a & 2533,58 & a & 4538,14 & a \\
\hline G1 & 3,60 & 40,03 & 309,67 & 1072,01 & $a b$ & 2573,69 & a & 4586,72 & a \\
\hline G2 & 3,62 & 41,55 & 324,95 & 1164,19 & $a b c$ & 2761,68 & $a b$ & 4621,08 & a \\
\hline G3 & 3,80 & 41,67 & 333,65 & 1200,25 & bc & 2868,92 & $a b$ & 4852,07 & $a b$ \\
\hline G4 & 3,93 & 42,53 & 340,31 & 1293,57 & bc & 2933,84 & $a b$ & 5201,59 & b \\
\hline G5 & 4,24 & 42,53 & 343,62 & 1330,02 & c & 3131,63 & $b$ & 5321,75 & $b$ \\
\hline BJND 5\% & ns & ns & ns & * & & * & & * & \\
\hline
\end{tabular}

Keterangan: Angka-angka yang diikuti huruf yang sama pada kolom yang sama tidak berbeda nyata berdasarkan uji BJND 5\% ;

ns : non signifikan ;

* : berpengaruh nyata

Tabel 4. Rata-rata Berat Basah (g), Berat Kering (g), dan Kadar Andrographolida (\%( Tanaman Sambiloto Pada Berbagai Perlakuan Dosis Pupuk Guano

\begin{tabular}{|c|c|c|c|c|c|}
\hline \multirow{2}{*}{ Perlakuan } & \multicolumn{2}{|l|}{$\begin{array}{l}\text { Berat } \\
\text { Basah }\end{array}$} & $\begin{array}{c}\text { Berat } \\
\text { Kering }\end{array}$ & \multicolumn{2}{|c|}{$\begin{array}{c}\text { Kadar } \\
\text { Andrographolida } \\
\end{array}$} \\
\hline & (g) & & (g) & & \\
\hline G0 & 78.94 & $a$ & 15.89 & a & 3.92 \\
\hline G1 & 81.72 & $a b$ & 16.54 & a & 4.42 \\
\hline $\mathrm{G} 2$ & 81.89 & $a b$ & 16.73 & $a$ & 4.49 \\
\hline G3 & 93.00 & $a b c$ & 18.67 & $a b$ & 4.42 \\
\hline G4 & 95.76 & bc & 21.14 & $b$ & 4.13 \\
\hline G5 & 102.65 & c & 21.33 & $b$ & 3.93 \\
\hline
\end{tabular}

BJND 5\% * * * * *

Keterangan : Angka-angka yang diikuti huruf yang sama pada kolom yang sama tidak berbeda nyata berdasarkan uji BJND 5\% ;

ns : non signifikan ;

* : berpengaruh nyata 
pertumbuhan yang sangat meningkat selama penelitian. Pada penelitian ini pengamatan ditekankan pada fase vegetatif tanaman yang meliputi tinggi tanaman, jumlah daun, luas daun, berat basah total tanaman, berat kering total tanaman dan kadar andrographolida tanaman sambiloto.

Berdasarkan hasil penelitian memperlihatkan bahwa perlakuan dosis pupuk guano memberikan pengaruh yang berbeda pada setiap parameter pengamatan. Hasilnya menunjukkan dosis pupuk guano 15 ton (G5) cenderung memberikan efek paling baik pada semua parameter pengamatan dari pada perlakuan tanpa pupuk guano (G0), 5 ton (G1), 7.5 ton (G2), 10 ton (G3), dan 12.5 ton (G4). Berdasarkan analisis sidik ragam Tabel 1 . menunjukkan nilai rata-rata tertinggi terdapat pada perlakuan dosis pupuk guano 15 ton (G5) pada semua umur tanaman (2 - $12 \mathrm{MST}$ ) dengan setiap pengamatan mengalami peningkatan, yaitu 4.13, 7.13, 14.90, 34.04, 52.44, dan $67.09 \mathrm{~cm}$. Hal ini disebabkan karena pemberian pupuk organik membutuhkan volume yang lebih tinggi karena kandungan hara dari pupuk organik pada umumnya lebih rendah dibandingkan dengan pupuk anorganik (Sarawa et al., 2012). Dalam pupuk guano terdapat unsur hara yaitu N, P, K dan kandungan hara dalam bentuk Ca-P sehingga guano dapat mengandung $P$ yang tinggi yang biasa disebut fosfor. Fosfor berperan dalam penyusunan inti sel, pembelahan sel, meningkatkan perakaran dan bunga, buah serta biji (Gardner et al., 1991).
Daun secara umum merupakan organ penghasil fotosintat utama. Pengamatan jumlah daun sangat diperlukan sebagai salah satu indikator pertumbuhan yang dapat menjelaskan proses pertumbuhan suatu tanaman (Sitompul dan Guritno, 1995). Perlakuan dosis pupuk guano tidak memberikan pengaruh nyata terhadap jumlah daun pada umur 2, 4, dan 6 MST. Hal ini disebabkan pupuk guano termasuk pupuk slow release dimana unsur hara dalam pupuk dilepaskan secara perlahan dan terus-menerus dalam jangka waktu tertentu sehingga kehilangan unsur hara oleh air lebih kecil. Pelepasan unsur hara pupuk alami lebih lambat dibandingkan pupuk kimia sehingga pengaruh yang diberikan terhadap pertumbuhan tanaman juga lambat terlihat (Yuliawaty, 2007). Namum pada umur 8,10 , dan 12 MST berpengaruh nyata. Pada Tabel 2. menunjukkan rata-rata jumlah daun dengan nilai tertinggi terdapat pada perlakuan dosis pupuk guano 15 ton (G5) pada semua umur tanaman (2 - 12 MST), sedangkan nilai rata-rata jumlah daun terendah terdapat pada perlakuan tanpa pupuk guano (G0) pada semua umur tanaman (2 - 12 MST). Dengan bertambahnya umur tanaman, ukuran dan jumlah daun akan meningkat. Hal ini disebabkan karena pertumbuhan tanaman sangat dipengaruhi oleh unsur-unsur hara yang diberikan.

Tabel 3. nilai rata-rata luas daun tertinggi terdapat pada perlakuan dosis pupuk guano 15 ton (G5) yaitu, $5321.75 \mathrm{~cm} 2$ sedangkan nilai ratarata luas daun terendah terdapat pada perlakuan tanpa pupuk guano (G0), yaitu $4538.14 \mathrm{~cm} 2$. Hal

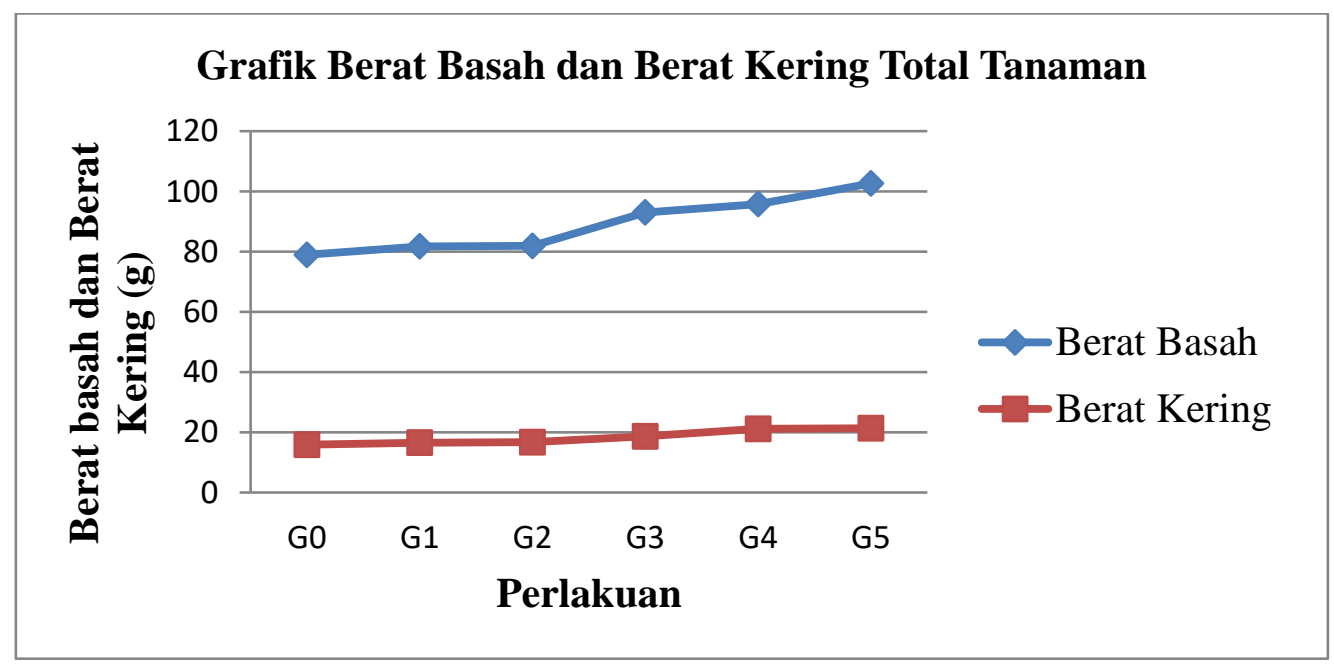

Gambar 1. Grafik Rata-rata Berat Basah dan Berat Kering Pada Berbagai Dosis Pupuk Guano 
ini karena dengan bertambahnya dosis pupuk guano yang diberikan akan meningkatkan kemampuan tanaman melakukan fotosintesis sehingga dapat meningkatkan luas daun. Hal ini sejalan dengan pendapat Sitompul dan Guritno (1995), bahwa luas daun tanaman ditentukan oleh jumlah bahan hasil fotosintesis yang dialokasikan ke bagian daun.

Berat basah tanaman merupakan akumulasi produk fotosintesis maupun penyerapan hara dalam bentuk senyawa organik penyusun seluruh jaringan pada organ vegetatif maupun generatif tanaman (Bidwell, 1979). Selain bahan organik, kandungan air pada jaringan tanaman akan mempengaruhi berat basah tanaman (Sitompul dan Guritno, 1995). Pada berat basah total tanaman Tabel 4. menunjukkan nilai ratarata tertinggi terdapat pada perlakuan dosis pupuk guano 15 ton (G5) yaitu $102.65 \mathrm{~g}$ dibandingkan dengan perlakuan lainnya. Hal ini karena pemberian dosis pupuk guano 15 ton (G5) dapat membantu penyediaan unsur hara tanaman, sehingga berpengaruh pada pertumbuhan vegetatif tanaman sambiloto yang pada akhirnya dapat meningkatkan berat basah total tanaman. Menurut safief (1985), berat basah tanaman terutama dipengaruhi tersediannya unsur hara $\mathrm{N}$ dan $\mathrm{P}$ yang berperan dalam pertumbuhan vegetatif.

Berat kering tanaman merupakan akibat efisiensi penyerapan dan pemanfaatan radiasi matahari yang tersedia, sepanjang musim pertumbuhan oleh tajuk tanaman (Gardner et al., 1991). Berdasarkan Tabel 4. menunjukkan bahwa nilai rata-rata berat kering total tanaman tertinggi dihasilkan oleh perlakuan dosis pupuk guano 15 ton (G5) yaitu $21.33 \mathrm{~g}$, sedangkan untuk nilai rata-rata terendah terdapat pada perlakuan (G0) tanpa perlakuan yaitu $15.89 \mathrm{~g}$. Hal ini disebabkan karena dengan pemberian dosis pupuk yang tinggi dapat membantu penyediaan unsur hara yang lebih banyak, sehingga kebutuhan unsur hara tanaman tercukupi. Berat kering tanaman berasal dari hasil fotosintesis dan serapan unsur hara yang diolah melalui proses biosintesis, didukung pendapat Kusumo (1984) bahwa penambahan berat kering tanaman erat kaitannya dengan aktifitas fotosintesis yang sangat membutuhkan unsur hara tanaman. Menurut Sitompul dan Guritno (1995), Bahwa produksi tanaman lebih akurat dinyatakan dengan ukuran bobot kering dari pada bobot segar tanaman karena masih sangat dipengaruhi oleh kondisi kelembaban pada saat itu.

Andrographolida adalah kandungan kimiawi utama yang dimiliki tanaman sambiloto yang merupakan senyawa diterpen lakton, berupa Kristal tak berwarna dan mempunyai rasa yang sangat pahit (Chao dan Lin, 2010). Hasil analisis sidik ragam pada kadar andrographolida tanaman sambiloto menunjukkan bahwa perlakuan dosis pupuk guano berpengaruh nyata terhadap kandungan andrographolida tanaman sambiloto. Pada Tabel 4. menunjukkan nilai ratarata tertinggi terdapat pada perlakuan 7.5 ton

Tabel 5. Rata-rata Berat Kering (g), dan Kadar Andrographolida (\%) dan (mg) Tanaman Sambiloto Pada Berbagai Perlakuan Dosis Pupuk Guano

\begin{tabular}{cccccccc}
\hline \multirow{2}{*}{ Perlakuan } & \multicolumn{2}{c}{$\begin{array}{c}\text { Berat } \\
\text { Kering }\end{array}$} & \multicolumn{2}{c}{$\begin{array}{c}\text { Kandungan } \\
\text { Andrographolida }\end{array}$} & \multicolumn{2}{c}{$\begin{array}{c}\text { Produksi } \\
\text { Andrograpolida }\end{array}$} \\
\cline { 2 - 7 } & $\mathbf{( g )}$ & & & \% & & (mg) \\
\hline G0 & 15.89 & a & 3.92 & a & 6.23 \\
G1 & 16.54 & a & 4.42 & c & 7.31 \\
G2 & 16.73 & a & 4.49 & & c & 7.51 \\
G3 & 18.67 & ab & 4.42 & c & 8.25 \\
G4 & 21.14 & b & 4.13 & b & 8.73 \\
G5 & 21.33 & b & 3.93 & a & 8.38 \\
\hline
\end{tabular}

BJND 5\%

Keterangan : Angka-angka yang diikuti huruf yang sama pada kolom yang sama tidak berbeda nyata berdasarkan uji BJND 5\% ;

${ }^{*}$ : berpengaruh nyata 
pupuk guano (G2) yaitu $4.49 \%$, sedangkan nilai rata-rata terendah terdapat pada perlakuan tanpa pupuk guano (G0) yaitu $3.92 \%$.

Pemberian pupuk yang tinggi dengan dosis 15 ton (G5) memberikan hasil berat basah dan berat kering yang tinggi, tetapi belum tentu meningkatkan kadar kandungan andrographolida yang tinggi. Hal ini diduga pada pemupukan guano dengan dosis 7.5 ton, tanaman sambiloto mengalami stressing sehingga kandungan andrograpolida lebih tinggi dibandingkan dengan pemupukan dosis yang tinggi. Stressing dalam tumbuhan adalah suatu keadaan hambatan eksternal yang membatasi kecepatan produksi bahan kering dari semua bagian tumbuhan, misalnya kekurangan air, cahaya, mineral, unsur hara, dan suhu diatas atau dibawah optimal (Grime, 1984). Hal ini sejalan dengan penelitian Mariani (2009), kandungan andrographolida yang tinggi belum tentu produksi biomassa juga tinggi, begitu juga sebaliknya.

Namun demikian, apabila kandungan andrograpolida (dalam \%) dikalikan dengan berat kering tanaman (dalam gram) maka akan diperoleh nilai kandungan/produksi andrograpolida (dalam satuan miligram) seperti disajikan pada Tabel 5.

Pada Tabel 5 terlihat bahwa nilai tertinggi kandungan/produksi andrograpolida dalam satuan milligram (mg) ditunjukkan oleh perlakuan G4 $(8.73 \mathrm{mg})$ diikuti oleh perlakuan G5 (8.38 mg) dan G3 (8.25 mg) kemudian G2, G1 dan G0 masing-masing dengan kandungan andrograpolida 7.51, 7.31 dan $6.23 \mathrm{mg}$ (terendah).

\section{KESIMPULAN DAN SARAN}

Perlakuan dosis pupuk guano memberikan pengaruh nyata terhadap parameter tinggi tanaman, jumlah daun, dan luas daun pada umur 8,10 , dan 12 MST. Pemupukan guano pada dosis 15 ton/ha (G5) merupakan dosis terbaik untuk parameter tinggi tanaman, jumlah daun, luas daun, berat basah dan berat kering total tanaman sambiloto. Perlakuan dosis pupuk Guano 7.5 ton/ha (G2) memberikan kandungan andrographolida tertinggi (4.49\%). Sedangkan kandungan/produksi andrograpolida tertinggi
(8.73 mg) ditunjukkan oleh perlakuan dosis pupuk guano 12.5 ton/ha (G4).

Untuk mendapatkan produksi andrographolida yang tinggi sebaiknya menggunakan dosis pupuk guano 12.5 ton/ha. Perlu dilakukan penelitian lebih lanjut tentang macam pupuk organik yang lain terhadap pertumbuhan dan kandungan andrographolida pada tanaman sambiloto.

\section{DAFTAR PUSTAKA}

Bidwell RGS. (1979). Plant Physiology. 2nd ed. Macmillan. New York.

Chao, W., \& Lin, B. (2010). Isolation and identification of bioactive compounds in Andrographis paniculata (Chuanxinlian). Chin Med 5, 17. https://doi.org/10.1186/1749-8546-5-17

Gardner, F.P., Pearce, R.B., \& Mitchell, R.L. (1991). Fisiologi Tanaman Budidaya. Diterjemahkan oleh: Susilo, H. Universitas Indonesia Press. Jakarta. 424 hal

Grime, J.P. (1981). Plant Strategies in shade, in: Plants and Daylight Spectrum $(\mathrm{H}$. Smith, editor), 159-186, Academic Press, New York.

Harjadi, S.S. (1996). Pengantar Agronomi. Cetakan ke-12. Gramedia Pustaka Utama. Jakarta. 195 hal.

Herbert. (1995). Biosintesis Metabolit Sekunder. IKIP Semarang Press. Semarang

Kartasapoetra, G. (1992). Budidaya Tanaman Berkhasiat Obat. Rineka Cipta. Jakarta.

Kusumo, K. (1984). Zat Pengatur Tumbuh. CV Yasa Guna. Jakarta.

Lingga, P. \& Marsono, M. (2000). Petunjuk Penggunaan Pupuk. Penebar Swadaya. Jakarta. 
Mariani, S. M. (2009). Pengaruh Intensitas Naungan dan Kombinasi Pemupukan $\mathrm{N}$ dan P Terhadap Pertumbuhan, Produksi Simplisia Serta Kandungan Andrographolida Pada Sambiloto (Andrographis paniculata). Bogor: Institut Pertanian Bogor

Pujiasmanto, B., Sunu, P., Toeranto, T., \& Imron, A. (2013). Pengaruh Macam dan Dosis Pupuk Organik terhadap Pertumbuhan dan Hasil Tanaman Sambiloto (Andrographis paniculata Ness.). Sains Tanah-Journal of Soil Science and Agroclimatology, 6(2), 81-90.

Sarawa, S., Nurmas, A., \& Dasril, M. A.J. (2012). Pertumbuhan dan Produksi Tanaman Kedelai (Glycine max L.) yang Diberi Pupuk Guano dan Mulsa Alang-Alang. Jurnal Agroteknos. 2(2). hal. 97-105.
Sarief, E. S. (1985). Kesuburan dan Pemupukan Tanah Pertanian. Pustaka Buana. Bandung.

Sedyarso, S. (1999). Pengaruh Beberapa Pupuk Organik Terhadap Pertumbuhan dan Hasil Tanaman Wortel (Daucus corata). Jurnal Hortikultura. 2(1): 16-21.

Sitompul, S.M., \& Guritno, B. (1995). Fisiologi Tumbuhan Jilid I. Diterjemahkan Oleh: Lukman, et all. Institut Teknologi Bandung. 241 hal.

Winarto, W., \& Karyasari, K. (2004). Sambiloto dan Budidaya pemanfaatan untuk Obat. Penebar Swadaya. Jakarta.

Yuliawaty, L. (2007). Pengaruh Pemberian Pupuk N-P-K Alami Terhadap Pertumbuhan Dan Produksi Tanaman Sambiloto (Andrograpis Paniculata (Burrn.f.) Ness.) Bogor: Institut Pertanian Bogor 